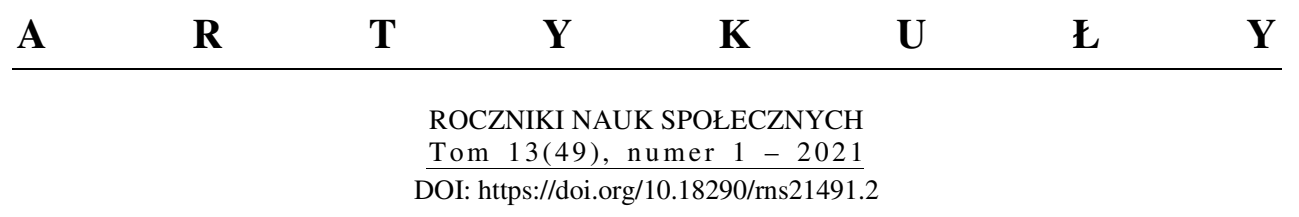

IWONA HOFMAN

\title{
KULTURA W PROGRAMACH JERZEGO GIEDROYCIA
}

Celem artykułu jest omówienie tematyki kulturalnej z łamów miesięcznika „Kultura” w kontekście funkcji kulturotwórczej mediów oraz medialnych strategii dyplomacji kulturalnej. „Kultura”, ukazująca się w latach 1947-2000 jako periodyk Instytutu Literackiego w Paryżu, stanowi bardzo dobrą egzemplifikację wykorzystania tematyki kulturalnej w programie czasopisma, powszechnie uważanego za polityczne. Mówiąc o tematyce kulturalnej, mam na myśli recenzje, omówienia i sprawozdania, obecność form literackich (prozy i poezji), kroniki emigracyjne. W głębszej warstwie - udział w tworzeniu i realizacji programu „Kultury” tak wybitnych postaci, jak Gustaw Herling-Grudziński, Czesław Miłosz, Juliusz Mieroszewski, Józef Czapski, Konstanty Jeleński, Wojciech Skalmowski, Leszek Szaruga (stale piszący o książkach); zasady współpracy i wybitną rolę stymulującą i promotorską wobec tych i wielu innych twórców emigracyjnych oraz krajowych dokumentuje korespondencja Jerzego Giedroycia. Należy zauważyć, że tematyka kulturalna zajmowała stałe i ważne miejsce w kompozycji „Kultury”, także ze względu na przekonanie Giedroycia o konieczności prowadzenia szczególnej akcji edukacyjnej kształtującej postawy zrozumienia i szacunku dla innych narodów. Znakiem, który może być rozpatrywany medioznawczo, jest identyfikacja „Kultury” przez swoisty podtytuł: „Szkice. Opowiadania. Sprawozdania”, widniejący na każdej okładce pisma; nawet wtedy, gdy w opinii publicznej i oddziaływaniu społecznym „Kulturze” przypisywano głównie funkcje polityczne (określenie gatunkowe „szkice” umniejsza znaczenie artykułów programowych).

Prof. dr hab. IwONA HofMAN - Instytut Nauk o Komunikacji Społecznej i Mediach, Uniwersytet Marii Curie-Skłodowskiej; adres do korespondencji: ul. Głęboka 45, 20-612 Lublin; e-mail: iwonahofman@gmail.com; ORCID: https://orcid.org/0000-0003-0492-5169. 
Pierwszy numer „Kultury” ukazał się w okresie rzymskim Instytucie Literackim, założonym w 1946 roku. Jerzy Giedroyc (1906-2000), podporucznik, pracownik Wydziału Prasy i Wydawnictw II Korpusu gen. Władysława Andersa, mający doświadczenia redagowania i wydawania czasopism (przed II wojną światową m.in. „Buntu Młodych”, „Polityki”, w trakcie służby wojskowej - gazet frontowych) przeczuwał, że zdemobilizowani żołnierze i rzesza emigrantów będą potrzebowali polskiego słowa na równi z pracą i stabilizacją. Instytut wydawał albumy pamiątkowe, słowniki, poradniki i książki. Nie przypadek spowodował, że wśród pierwszych tytułów znalazły się Księgi narodu polskiego i pielgrzymstwa polskiego Adama Mickiewicza, Prometeusze Stanisława Szpotańskiego, Dziennik podróży do Austrii i Niemiec Jerzego Stempowskiego, Portret Kanta i trzy essaye o wojnie Bolesława Micińskiego. Szczególnie dwie książki miały znaczenie programowe: Księgi, poprzedzone wstępem Herlinga-Grudzińskiego, i Prometeusze, gdyż obie dotyczyły emigracji - idei, powinności, bytu na uchodźstwie. Giedroyc planował wydanie biblioteki myśli politycznej (Stanisław Brzozowski, Józef Piłsudski, Roman Dmowski, Ludwik Krzywicki), klasyki (działa Henryka Sienkiewicza, Władysława Reymonta, Andrzeja Struga, Juliusza Kadena-Bandrowskiego), licząc na dobre wyniki sprzedaży literatury popularnej (np. autorstwa Sergiusza Piaseckiego). Jednak szybko ubożejący żołnierze nie okazali się tak dobrymi odbiorcami, Instytut nie miał zaplecza finansowego i wsparcia (aczkolwiek był powołany rozkazem organizacyjnym gen. Kazimierza Wiśniowskiego, datowanym na 28 września 1946 roku, w porozumieniu z Rządem RP w Londynie), dlatego Giedroyc - po rozmowach z Herlingiem-Grudzińskim i Zofią Hertz - podjął próbę wydawania czasopisma. „Kultura” miała być dodatkiem do zasadniczej działalności Instytutu, obliczonej już wówczas na długofalowy proces edukacji społecznej i obywatelskiej emigracji. W skład pierwszej redakcji wchodzili poza Giedroyciem: Herling-Grudziński, Hertz, Czapski, a w pierwszym numerze znajdowały się teksty: Paula Valéry'ego, Benedetto Crocego, Tymona Terleckiego, Zygmunta Zaremby, Mariana K. Dziewanowskiego, Andrzeja Bobkowskiego, Wiktora Weintrauba, Tadeusza J. Krońskiego, Czapskiego, Arthura Koestlera, Herminii Naglerowej, Frederico Garcii Lorki. Wraz z przeprowadzką do Francji utrwalił się zwyczaj wspólnego mieszkania członków redakcji, a ściślej - najbliższych współpracowników Giedroycia. W Maisons-Laffitte (pod dwoma kolejno adresami) powstał Dom „Kultury” (por. Kowalczyk, 1999; Chruślińska, 2003; Kerski, Kowalczyk, 2001; Nowinowski, 2019; Pomian, 2000; Korek, 2000; Hofman, 2011, 2019). 
Fenomen „Kultury” polega na tym, że w relatywnie krótkim czasie (zgodnie $\mathrm{z}$ wewnętrzną periodyzacją historii miesięcznika do początku lat 50. XX wieku), z projektu uzupełniającego ofertę wydawniczą Instytutu stała się emblematem niepodległościowego ośrodka emigracyjnego. Oceniając zawartość 654 numerów miesięcznika, można mówić o długim trwaniu, znaczeniu stylu pracy Giedroycia - Redaktora (w literaturze podmiotu, tylko dla Giedroycia, jest rezerwowane takie, i tak pisane - wielką literą, określenie), aktualności przesłania programowego, niepodważalnym zbiorze wartości ideowych stanowiących o renomie „Kultury” jako emanacji ośrodka politycznego.

W okresie tworzenia pisma prymat na emigracji przypadał Mieczysławowi Grydzewskiemu, który w Londynie, od 1946 roku, redagował tzw. bezprzymiotnikowe „Wiadomości”, będące w każdym aspekcie depozytariuszem dwudziestolecia międzywojennego. Za takim pozycjonowaniem „Wiadomości” przemawiają m.in. analiza doboru autorów, mocno zakorzenionych w międzywojniu, tematyka i układ działów problemowych, przewaga materiałów wspomnieniowych, sekundowanie polityce rządu londyńskiego (np. w sprawie nieuznawania granicy wschodniej, polityce Polski, odcięciu od kontaktu z Krajem). „Wiadomości” ukazywały się do 1981 roku, tracąc znaczenie jako tygodnik opiniotwórczy wskutek naturalnego odchodzenia powojennych czytelników (zob. Habielski, 1991, 2000; Friszke, Habielski, Machcewicz, 1999). „Kultura" wychodziła do września 2000 roku - śmierć Giedroycia oznaczała zamknięcie pisma.

W świetle korespondencji Giedroycia z Jeleńskim, Miłoszem, Herlingiem-Grudzińskim oraz na podstawie wypowiedzi Giedroycia, Witolda Gombrowicza, Bobkowskiego można powiedzieć, że spór o charakter „Kultury" - polityczny czy społeczno-kulturalny - towarzyszył pismu od chwili powstania. Na okładce pierwszego numeru jako redaktorzy figurują Giedroyc i Herling-Grudziński, co po latach można odczytać jako symboliczne zestawienie przeciwstawnych koncepcji rozwoju „Kultury”. Istnieje wiele udokumentowanych dyskusji, m.in. korespondencyjnych, na temat przewagi problemów politycznych i deficytu kultury, choć można z nimi polemizować, analizując strukturę podziału treści w każdym numerze i stałą obecność poezji, opowiadań, dzienników. Być może ta krytyczna refleksja wynikała z literalnego odczytania nagłówków cykli i rubryk, m.in. „Archiwum polityczne”, „Kraj”, „Sąsiedzi”, „O religii bez namaszczenia”, „Sprawy i troski”, i dopiero dalej np. „Kronika kulturalna”, „Książki” (Kopczyński, 1990; Kudelski, 1995; Rodak, 2011). Sam Giedroyc, wielokrotnie pytany o swoją ocenę „Kultury”, mawiał: jest „raczej ośrodkiem politycznym”, „naszą rolą jest obserwowanie 
sytuacji i dawanie rad w miarę naszych możliwości i kompetencji”, „całą naszą siłą jest to, że staramy się bardzo realistycznie mówić prawdę, jakakolwiek ona jest, nawet najbardziej nieprzyjemna"".

W kręgu „Kultury” powstały i rozwijały się koncepcje polityczne związane z projektowaniem miejsca Polski w wolnym i demokratycznym świecie. Tematycznie publicystykę tę można ułożyć w bloki: program wschodni, program zachodni, jednoczenie Europy, oddziaływanie na Kraj.

„Kultura” jest przykładem doskonałego przenikania się publicystyki i myśli politycznej, a sam Giedroyc lokował swoje zainteresowania w polityce. Twierdząc, że jest niepiszącym redaktorem, powierzał formułowanie tekstów programowych publicystom, których obdarzał zaufaniem. Przez wiele lat, aż do śmierci w 1976 roku, rolę porte-parole Giedroycia pełnił Mieroszewski, twórca koncepcji wschodniej, zwanej ULB, od pierwszych liter nazw państw: Ukraina, Litwa, Białoruś. Uwzględniając zmienne wielkiej polityki mocarstw, Mieroszewski rozpisywał scenariusze sytuacji w Europie Wschodniej, mając niezmienny pogląd, że ZSRR ulegnie rozpadowi wskutek dążeń narodowo-wyzwoleńczych. Mieroszewski przyjął za pewnik, że Ukraina, Litwa i Białoruś będą naturalnymi sojusznikami Polski w warunkach suwerenności i samostanowienia, a ścisła współpraca polityczna tych państw wpłynie na pozycję Polski w świecie. W 1974 roku Mieroszewski użył po raz pierwszy terminu ULB. Warto przytoczyć fragment odnośnego artykułu, gdyż zawiera on charakterystykę łączną programów „Kultury”:

Nasz program zachodni będzie sukcesem tylko wówczas, gdy nasz program wschodni będzie sukcesem. Tylko wtedy, gdy po odzyskaniu niepodległości zdołamy uładzić nasze stosunki z sąsiadami wschodnimi - zdołamy oprzeć się naciskowi zjednoczonych Niemiec. Francja i Anglia nie życzą sobie supermocarstwa niemieckiego w środku Europy - lecz Paryż i Londyn poprą Polskę pod warunkiem, że Polska z uładzoną granicą wschodnią stanowić będzie kartę, na którą warto postawić. Polsce usiłującej odebrać Ukraińcom Lwów na wschodzie i usiłującej bronić Wrocławia na zachodzie - nikt nie zaoferuje pomocy czy poparcia (Mieroszewski, 1974, s. 9).

W chwili formalizowania koncepcji wschodniej za pomocą tego tekstu mijało dwadzieścia dwa lata od słynnego i bardzo kontrowersyjnego dla emigrantów

1 „Tygodnik Mazowsze”, 8 października 1986, „Trybuna”, 3-4 października 1992, „ST.ART” $\mathrm{nr}$ 4, rok 2 (prawdopodobnie listopad 1993). Wszystkie cytaty pochodzą z książki Teczki Giedroycia, 2010, s. 109, 110, 111. Wypowiedzi te trudno określić bibliograficznie, gdyż pochodzą z archiwum prywatnego Giedroycia, mają formę nieopisanych wycinków prasowych lub odręcznych notatek Redaktora. 
listu ks. Józefa Majewskiego (1952), w którym ten czytelnik „Kultury” wypowiedział się za symbolicznym uznaniem i odstąpieniem Wilna i Lwowa jako zapowiedzi przewartościowania przedwojennej polityki Polski wobec sąsiadów i mniejszości narodowych. Giedroyc zdecydował się na druk tego listu świadom, że reakcje odbiorców pisma będą swoistym probierzem nastrojów emigracji, ale przede wszystkim będą odpowiedzią na pytania o realność założeń polityki wschodniej, opartej na rewizji historii i gotowości do zaprzestania licytacji krzywd ${ }^{2}$. Pewną rolę $w$ zapoczątkowaniu programu wschodniego odegrał tekst Józefa Łobodowskiego Przeciw upiorom przeszłości (1952), wyrażający wprost oczekiwanie, że Polacy i Ukraińcy dokonają rozrachunku z przeszłością, skupiając się na wizji przyszłości. Giedroyc podejmował także inne działania potwierdzające znaczenie Ukrainy w koncepcji ULB, np. wydanie przez Instytut antologii Rozstrzelane odrodzenie w 1959 roku, podpisanie „Deklaracji w sprawie ukraińskiej” w 1977 roku. Wzmocnił, poprzez swój akces, tworzone w 1974 roku przez Władimira Maksimowa pismo „Kontynent”. Równolegle w „Kulturze” były omawiane różne projekty federacyjne jako sposób na przezwyciężenie kompleksu rosyjsko-niemieckiego w Europie Środkowej i Wschodniej; przykładowo publicystyka Józefa Marii Bocheńskiego, wystąpienie Czapskiego podczas Kongresu Wolności Kultury w Berlinie w 1950 roku.

Wartość publicystyki Mieroszewskiego polega na tym, że przełamał tabu wobec mitologizowanych Kresów, przedstawiając wiarygodne, wieloaspektowe analizy konieczności zmiany w polityce wschodniej oraz korzyści z łączenia nowego paradygmatu wschodniości z kwestią rosyjską, „europeizacją Rosji” (por. Mieroszewski, 1956, 1957, 1964, 1967a, 1967b, 1970, 1972, 1973a, 1973b) $)^{3}$. Oponentami Mieroszewskiego byli m.in. Stanisław Paprocki, Zygmunt Nagórski, Adam Pragier, Stanisław Zarzewski, Wojciech Wasiutyński. Kontynuatorami - Bohdan Osadczuk, Stefan Kozak, Mirosław Czech, Leopold

\footnotetext{
${ }^{2}$ W reakcji na żywą dyskusję ukazało się podsumowanie Nota Redakcji. Nieporozumienie czy tani patriotyzm (1953). W tym kontekście ważne są słowa Giedroycia: „Z wytycznych, które nam przyświecały, najważniejsze było odpowiedzenie sobie na pytanie, jaką rolę winna Polska odgrywać we wschodniej Europie. Nasze założenia ideowe wiązały się w pewnym sensie z koncepcjami Józefa Piłsudskiego, ma się rozumieć zmodyfikowanymi. Doszliśmy więc do przekonania, że rola Polski na Wschodnie jest nadal ogromna, ale inna niżby to wynikało z koncepcji jagiellońskich [...]. Aby naszą politykę oprzeć na nowych podstawach i nie być posądzonym o imperializm, trzeba było zdecydować się na ofiary [...]. Dlatego też nasz zespół od razu się zdecydował, jeszcze w 1949 roku, że Wilno i Lwów są dla Polski stracone. [...] Musimy zrezygnować z rewindykacji tych ziem nawet po zmianie sytuacji. Tym się różniliśmy od reszty emigracji, która sprawę utraconych ziem chce odłożyć do czasu odzyskania niepodległości przez Polskę" (Droga na Wschód, 1989, s. 44).

${ }^{3}$ Zob. także: Habielski, 1997, s. 23-32.
} 
Unger, Roman Szporluk, Bogumiła Berdychowska, Piotr Wandycz, Mykoła Riabczuk, Aleksander Hrycenko (tylko w odniesieniu do koncepcji ULB).

Program zachodni „Kultury” wyznaczają następujące kwestie: „Jako pragmatycy nie jesteśmy w Kulturze ani pro-rosyjscy ani anty-rosyjscy ani proniemieccy ani anty-niemieccy staramy się tylko być konsekwentnie polscy" (Mieroszewski, 1967c, s. 79), „Nasz los przestał być funkcją stosunku Rosji do Niemiec i jest dziś w pewnej mierze funkcją stosunku Rosji do Stanów Zjednoczonych” (Mieroszewski, 1967b, s. 39), ,przepołowione Niemcy w przepołowionej Europie, zjednoczone Niemcy w zjednoczonej Europie" (Mieroszewski, 1962, s. 154). Stanowią one kwintesencję myślenia Giedroycia (należy pamiętać o jego inspirującej roli) na temat uczestnictwa Niemiec w powojennej Europie. Redaktor uważał, że w federacji europejskiej wpływy Niemiec zostałyby zrównoważone wpływem innych państw, że granica na Odrze i Nysie Łużyckiej gwarantuje stabilizację polityczną w Europie, że konieczne jest pojednanie polsko-niemieckie przy zachowaniu pamięci o II wojnie światowej (por. Pomian, 1999; Szaruga, 2001; Friszke, 2007). Kluczowym zagadnieniem było uznanie powojennych granic i umiędzynarodowienie sprawy zniewolonych narodów Europy Wschodniej, tj. wzbudzenie poczucia odpowiedzialności za losy Wschodnich Europejczyków i wprowadzenie tej problematyki do agendy publicznej w państwach demokracji zachodniej. Adekwatny zbiór publicystyki Mieroszewskiego, w opisie historycznym dorobku „Kultury” wzmacniali m.in. Osadczuk („Berlińczyk”), Unger, Karol Baumgarten, Andrzej Chilecki, Aleksander Kawałkowski, Basil Kerski, Andrzej Stach, Jan Józef Lipski, Stempowski, Szaruga. Należy podkreślić, że od pobytu Giedroycia i Czapskiego na Kongresie berlińskim datuje się szczególne zainteresowanie budowaniem płaszczyzn pojednania polsko-niemieckiego, co tak bardzo wyróżniało „Kulturę” na tle ośrodków emigracji ${ }^{4}$. Relatywnie szybko uruchomiono kronikę niemiecką, a w 1984 roku ukazał się specjalny niemieckojęzyczny zeszyt „Kultury”.

Zarówno koncepcja wschodnia, jak i program zachodni były omawiane w perspektywie procesów jednoczenia Europy. Można nawet przyjąć, że idea dobrosąsiedztwa stanowiła element rozważań szans na integrację, więcej niż gospodarczą. W nurcie publicystyki ideowej mieszczą się artykuły relacjonujące

\footnotetext{
${ }^{4}$ Giedroyc tak skomentował pobyt w Berlinie: „Tym, co zrobiło szczególne wrażenie na publiczności niemieckiej, było podkreślenie przez Czapskiego potrzeby pojednania między Polską i Niemcami. Był on prekursorem późniejszych inicjatyw zmierzających w tym kierunku" (Giedroyc, 1994, s. 174). Wiele informacji o kuluarach spotkań w Berlinie i ocenie możliwości m.in. ustanowienia korespondenta ( $w$ tej roli Giedroyc widział Mieroszewskiego) zawiera korespondencja ze Stempowskim i Wańkowiczem.
} 
fakty historyczne w toku procesów jednoczenia, regionalne aspekty zjednoczenia, plany neutralizacji i federacji, miejsce Niemiec w Europie, pozycja Polski na tle stosunków z Rosją, Ukrainą, Litwą i Białorusią. Ich autorem byli m.in. Raymond Aron, James Burnham, Melchior Wańkowicz, Mieroszewski, Stefan W. Kozłowski, Jerzy Prądzyński, Theodor Oberländer, Krzysztof Gawlikowski, Karol Modzelewski, Andrzej Koraszewski, Stefan Abner. Refleksje zjednoczeniowe występują do ostatniego numeru „Kultury” i zawsze są związane z projektami miejsca Polski w Europie, w tym: jako promotora proeuropejskich warstw Ukraińców.

Program krajowy wynikał z założenia trwałości pojałtańskiego ładu geopolitycznego i przekonania o ewolucyjności ustroju komunistycznego. Giedroyc podjął akcję oddziaływania na Kraj m.in. przez wysyłanie publikacji Instytutu, szeroką pomoc materialną dla Polaków za żelazną kurtyną, organizację stypendiów i staży zagranicznych dla twórców itp. Działania te były ukierunkowane na dotarcie z wolnym słowem do Polski i państw sąsiednich, a Redaktor zyskał wsparcie w Rozgłośni Polskiej Radia Wolna Europa (choć nie można powiedzieć, że osobiste relacje z dyrektorem RP RWE, Janem Nowakiem-Jeziorańskim, układały się wzorowo) (Hofman, 2007, 2009a). Nadająca z Monachium od 3 maja 1952 roku Rozgłośnia Polska miała znacznie szerszy zasięg (mimo zagłuszania) niż słowo drukowane. Nowak-Jeziorański, doceniając znaczenie „Kultury”, regularnie zamieszczał w programach omówienia zawartości numerów, a także organizował rozmowy okrągłego stołu wokół treści programowych. Dostęp do niecenzurowanych wiadomości był sprawą kluczową dla ruchów dysydenckich i opozycyjnych. „Kultura” i RP RWE ośmielały do myślenia inaczej, do sprzeciwu wobec propagandy i zakłamywania rzeczywistości. Ich aktywność, nawet w okrojonej formie komunikacji medialnej, sprzyjała powstaniu społeczno-politycznych i kulturowych ruchów niezależnych, np. podziemnego ruchu wydawniczego. Od połowy lat 70 . XX wieku „Kultura” pełniła już rolę forum krajowej myśli niepodległościowej, udostępniając łamy intelektualistom, działaczom, kronikarzom opozycji. Giedroyc dbał o zaopatrzenie polskich wydawnictw niezależnych w sprzęt poligraficzny, zwłaszcza w okresie Solidarności i w latach 80. XX wieku.

Giedroyc wielokrotnie powtarzał, że najważniejsza jest jakość publicystyki i szacunek do Słowa (dlatego pisane wielką literą). Słusznie twierdził, że rzetelne dziennikarstwo oraz wiarygodni autorzy gwarantują oddziaływanie społeczne czasopisma. Mówiąc współczesnym językiem, budował markę „Kultury”, szczególnie uwzględniając: dbałość o warstwę faktograficzną i klarowny język analizy, istotność i adekwatność tematów (co przy dłuższym cyklu 
produkcyjnym miesięcznika rodziło ryzyko nietrafionych wypowiedzi programowych; są tego liczne dowody w korespondencji) ${ }^{5}$, jakość publicystyki, relacyjność rozumianą jako kręgi autorów „Kultury” i dialog z czytelnikami (działy kronik i listów), odpowiedzialność za Słowo w sensie weryfikacji faktów i założeń, ale także w płaszczyźnie moralno-etycznej (szacunek dla odbiorcy). Mieroszewski, wykładając podstawy funkcjonowania „Kultury”, napisał: „Słowo jest głównym instrumentem działania politycznego, ponieważ w ostatecznym rozrachunku zwyciężyć nie oznacza pobić, lecz zjednać. Zaś zjednać oznacza przekonać. Do prawdziwej współpracy można tylko kogoś zjednać, lecz nie przymusić" (1966, s. 49). Publicysta podkreślił pragmatyzm postawienia na Słowo, ale skrót: przekonanie-współdziałanie w istocie obejmuje funkcje mediów, w tym: scalającą, socjalizującą, kulturotwórczą, edukacyjną. Nie sądzę, aby Mieroszewski posługiwał się takimi kategoriami, ale pisząc w imieniu „Kultury”, zaakcentował siłę sprawczą poważnego dziennikarstwa.

W świetle badań spuścizny Giedroycia można przyjąć, że kategoria Słowa była dla niego prymarna w odniesieniu do obu płaszczyzn działania: politycznej i kulturowej. Słowo w programach politycznych oznaczało umiejętność określenia znaczenia faktów i przewidywania możliwych scenariuszy wydarzeń. Słowo w kulturze to przedruki literatury, ale także troska o wspólnotę i wyrażenie zrozumienia dla aspiracji kulturowych Innych. Były to nowoczesne poglądy, artykułowane w obliczu „zmierzchu cywilizacji”, jak pisał Croce w pierwszym zeszycie „Kultury”. W rozpoznaniu wagi problemu Innego na pewno pomogły Giedroyciowi doświadczenia urzędnika państwowego w przedwojennej Polsce, gdyż w swojej pracy w Ministerstwie Rolnictwa i Ministerstwie Przemysłu obserwował skutki polityki wobec mniejszości narodowych, etnicznych i religijnych. Stosunek do historii i odpowiedzialność za Słowo wyznaczały ramy programów Giedroycia. Uważał, że bez podjęcia prób wyjaśnienia zaszłości historycznych, poznania historii i aspiracji narodowych oraz kulturowych sąsiadów nie ma szans na pojednanie i konsolidację myśli niepodległościowej w Europie Wschodniej. Giedroyc był prekursorem dyplomacji kulturowej. Umiejętnie wplatał treści kulturowe w programy polityczne, bo wierzył, że edukacja obywatelska w tym zakresie wpłynie trwale na zmianę postaw wobec Innego, zmniejszy cząstkę obcości i zagrożenia w konstrukcie Innego. Na łamach „Kultury” znajdujemy wiele dowodów takiego myślenia. Programom politycznym towarzyszy swoista otoczka kulturowa, którą tworzą przedruki literatury, recenzje, eseje, kroniki. Te formy wypowiedzi były często

\footnotetext{
${ }^{5}$ Przykładowe sekwencje wpływu Giedroycia na tezy artykułów programowych omawiam w artykułach: Hofman, 2009, cz. 7, s. 207-224; 2018, s. 253-266.
} 
jedynymi znakami obecności emigracji wschodnioeuropejskiej w dyskursie medialnym i politycznym. Dawały nadzieję na zauważenie i pomoc w zachowaniu tożsamości narodowej. Proporcje materiałów politycznych i kulturowych można prześledzić w odniesieniu do ogniw koncepcji ULB i Niemiec.

Uruchomienie kronik z obszaru ULB równolegle z kronikami polskiej emigracji ${ }^{6}$ wpłynęło na recepcję „Kultury”. Było elementem strategii budowania zrębów dobrosąsiedzkich stosunków z Ukrainą, Litwą i Białorusią. Ich geneza wiązała się z pragnieniem uwolnienia wzajemnych relacji od zaszłości historycznych, spacyfikowania lęków o podłożu nacjonalistycznym, przewartościowania wspólnego dziedzictwa, wzbudzenia szacunku i otwartej postawy wobec problemów wschodnich sąsiadów. Kronikom towarzyszyła względnie stała kolumna „Wydarzenia miesiąca”, zawsze dwudzielna: „Zachód - Emigracja”, „Kraj - blok wschodni”, dzięki czemu miesięcznik stawał się lekturą dla przebywających na obczyźnie Rosjan, Ukraińców, Litwinów. Kronikę ukraińską na przestrzeni lat 1952-1999 redagowali: Osadczuk, Borys Łewyćkyj, Iwan Łysiak-Rudnicki, Andrzej Vincenz, Benedykt Heydenkorn, Dominik Morawski, Władysław Żeleński, Józef Darski (łącznie z kronikami litewską i białoruską). Uzupełnienie stanowiły: „Przegląd czasopism ukraińskich” (1957), „Wydawnictwa ukraińskie” (ukazywały się regularnie), „Z ULB” (1991), „Niepodległa Ukraina i Polska” (1992), „Z prasy ukraińskiej" (1992-1993). Poza wymienionymi wcześniej publicystami politycznymi aktywnymi twórcami tych rubryk byli także: Łobodowski, Ryszard Wraga, Bogusław Bakuła, Jurij Szewelow, Iwan Koszeliweć, Wołodymyr Małynowicz. Kronikę litewską redagował Edmund Jakubowski (E. Żagiell) w latach 1974-1990, a kolejne dwa lata - Darski. Pisali w niej m.in.: Wacław Zyndram-Kościalkowski, Tadeusz Katelbach, Stanisław Swianiewicz, Kazimierz Okulicz, M. Czech, Jan Widacki, Anna Strońska, Tomas Venclova. Pierwsza kronika białoruska ukazała się w 1955 roku, przygotowana przez A. Vincenza. Następnie, w latach 1977-1982, jej twórcą był Włodzimierz Brylewski, a po przerwie, w latach 1986-1992, Darski. Kronika wróciła jeszcze epizodycznie w 1999 roku jako uzupełnienie publicystyki Wiktora Sukiennickiego, ks. Romana Dzwonkowskiego, Mieczysława Jackiewicza, Sokrata Janowicza, Stanisława Szuszkiewicza. W latach 70. XX wieku ukazywało się także omówienie Białoruskie czasopisma na Zachodzie i Białoruskie pokłosie. Kontekstowo należy wymienić także rubryki: „W sowieckiej prasie”, następnie jako „Notatki rosyjskie”,

\footnotetext{
${ }^{6} \mathrm{~W}$ „Kulturze” ukazywało się 17 kronik, adekwatnych do państw osiedlenia polskich emigrantów: amerykańska, brazylijska, argentyńska, angielska, niemiecka, francuska itd. Na znaczenie kronik zwróciła uwagę jako pierwsza Grażyna Pomian, 1995; zob. też: Hofman, 2002, s. 87-99.
} 
opracowywane w latach 1969-1997 przez Michała Hellera (Adama Kruczka). W kronikach znajdowały się informacje społeczne-kulturalne, dające przekrojowy obraz sytuacji emigrantów i wydarzeń w republikach radzieckich. Metodologia pracy nad kronikami uwzględniała jako źródła prasę emigracyjną lub drugoobiegową, książki od niezależnych wydawców ${ }^{7}$, rzadziej - oficjalną prasę partyjno-rządową, czytaną à rebours. Emigranci czytali „Kulturę” pewni, że kroniki zawierają rzetelne informacje, a dla wielu z nich ten specyficzny, zapośredniczony kontakt z kulturą rodzimą stanowił jedyną platformę utrwalania własnej tożsamości. Z listów czytelników, zwyczajowo publikowanych na łamach „Kultury”, wynikało, że kroniki i rubryki pokrewne przyczyniły się do odrzucenia schematycznych ocen historii i kultury Ukraińców, Litwinów i Białorusinów.

Na łamach „Kultury” często gościły wiersze i fragmenty prozy ukraińskich twórców, które tłumaczył i komentował już od 1948 roku Łobodowski. Wprowadził on do obiegu czytelniczego poezje Jurija Kłena, Pawło Fyłypowicza, Mykoły Zerowa, Jewhena Małaniuka, Pawło Tyczyny, Maksyma Rylskiego, Iwana Bahrjanego, Ołeny Telihej. Giedroyc powierzył mu omówienie wspominanej wcześniej antologii Rozstrzelane odrodzenie, której tytuł stał się symbolem wiary w destalinizację pokolenia „szestydesiatników”, założycieli kijowskiego Klubu Młodzieży Twórczej (m.in. Wasyl Symonenko, Iwan Dracz, Iwan Dziuba, Iwan Switłyczny, Jewhen Swerstiuk, Mychajło Kociubynski, Ałła Horska, Wiktor Zarecki). Łobodowski pisał także o współczesnej literaturze ukraińskiej, neoklasykach kijowskich, ruchu wydawniczym, baśniowości i folklorze w literaturze ukraińskiej. Omawiał czasopisma i publikacje emigracyjne. Zamieszczał przejmujące szkice o losach twórców ukraińskich po 1938 roku $^{8}$; tu także odnotować należy artykuł Jurija Ławrynieńki, ocalałego z łagru pisarza, zatytułowany Literatura sytuacji pogranicznych (1959). Publicyści „Kultury” portretowali i analizowali twórczość Tarasa Szewczenki,

\footnotetext{
${ }^{7}$ Regularnie omawiano treści takiej prasy, jak m.in. (w układzie chronologicznym): „Rocznik Wołyński”, „Suczasna Ukraina”, „Ukraiński Wisti”, „Białoruski Zbornik”, „Belarussian Review”, „Literaturna Hazeta”, „Lituanus”, „Kronika Kościoła Katolickiego na Litwie”, „Aušra”, „Kontynent”, „Metmenys”, „Widnowa”, „Suczasnist””. Pełne wykazy tytułów prasowych i książek zawarłam w monografii Ukraina, Litwa, Białoruś w publicystyce paryskiej „Kultury” (2003, s. 54-60).

${ }^{8}$ Przykładowo można wymienić następujące artykuły Łobodowskiego: Ukraińska literatura emigracyjna, Kultura 1951, nr 4/54, s. 46-60, Młody las na obczyźnie, Kultura 1959, nr 10/156, s. 49-58, Scylle i Charybdy ukraińskiej poezji, Kultura 1954, nr 5/79, s. 35-50, Kultura 1954, nr 6/80, s. 24-49, Poezja Jewhena Mataniuka, Kultura 1955, nr 10/96, s. 32-38, Sąd nad umartym, Kultura 1966, nr 6/224, s. 3-8, O Maksymie Rylskim, Kultura 1966, nr 7/225-8/226, s. 30-37. O zaangażowaniu Łobodowskiego w promowanie literatury ukraińskiej pisali Ludmiła Siryk i Jerzy Święch w monografii Józef Łobodowski - rzecznik dialogu polsko-ukraińskiego, Lublin: Wydawnictwo UMCS 2000.
} 
Mykoły Bażana, Wasyla Stusa, Igora Kałyncia i innych. Najważniejsze jest to, że literatura ukraińska pojawiła się w polskim czasopiśmie emigracyjnym, obecna autonomicznie jako przejaw „literackości” „Kultury”, ale zarazem pełniąca funkcje w programach politycznych jako wyraz zainteresowania kulturą i tożsamością kulturową Ukraińców.

Nad tematyką stosunków polsko-litewskich wyraźnie dominowały spory o dziedzictwo Unii Lubelskiej. Dobrze obrazuje ton ten publicystyki zestawienie kilku artykułów, tj. W poszukiwaniu dialogu polsko-litewskiego Juozasa Girniusa, Dialog polsko-litewski Jerzego Iwanowskiego i Tadeusza Katelbacha z 1955 roku oraz Zgrzytliwe echo przesztości, podpisany „Redakcja”, z 1975 roku. Zasadnicze polemiki dotyczyły społecznych i kulturowych skutków osmozy dominującej, silniejszej kultury polskiej (Litwini pisali wprost - polonizacji). W znacznie późniejszym Liście otwartym do Litwinów i Polaków na Litwie Venclova (1989) wyliczał stereotypy i historyczne przeszkody na drodze do porozumienia, m.in. zanik kultury narodowej, status Wilna, akcję gen. Żeligowskiego. Wyrażając poglądy inteligencji litewskiej, podejmował próby racjonalizacji tego sporu. W tym miejscu warto przypomnieć słynny Dialog $o$ Wilnie Venclovy i Miłosza zawierający odmienne charakterystyki miasta i jego roli w historii Litwy i Polski'. W tym samym tonie Swianiewicz pisał o Uniwersytecie Stefana Batorego, a wyobrażeniowe wyprawy na Litwę podejmowali Sukiennicki i Józef Mackiewicz. W latach 90. XX wieku w „Kulturze" pojawiły się reportaże z Litwy pióra Andrzeja Romera, Ewy Berberyusz, Mieczysława Jackiewicza, Strońskiej. Wszystkie te teksty w pewnym sensie zbliżały do rozumienia kompleksu trudnych zagadnień pamięci o stracie. Giedroyc udostępniał łamy „Kultury” Litwinom, aby mogli w nieskrępowany sposób przedstawić swoje poglądy na temat wspólnej historii i koegzystencji kultury. Przywiązywał też wagę do funkcjonowania kroniki litewskiej, gdyż dla emigrantów była ona jedynym, relatywnie dostępnym źródłem informacji o życiu w republice litewskiej. Do stałych kwestii poruszonych przez E. Żagiella należały: szkolnictwo w języku litewskim, represje za wiarę, walka z rusyfikacją, podziemny ruch wydawniczy, samokształceniowe kółka młodzieżowe,

\footnotetext{
${ }^{9}$ Dla ilustracji przytaczam dwa cytaty: Miłosz - ,[...] ni to Polska, ni to nie Polska, ni to Litwa, ni to nie Litwa, ni to stolica, ni to prowincja [...]. Wilno, jak widzę z perspektywy, było dziwaczne, miasto pomieszanych, zachodzących na siebie stref”; Venclova - „Znamy nie to samo Wilno, nawet można powiedzieć, że to są dwa krańcowo różne miasta”, „Dla Polaków Wilno było ośrodkiem kulturalnym na Kresach, ważnym, ale przecież prowincjonalnym. Dla Litwinów to symbol ciągłości oraz tożsamości historycznej, coś w rodzaju Jerozolimy [...]. Bo Litwa bez Wilna jest państwem - efemerydą, a z Wilnem zdobywa całą swoją przeszłość i całą historyczną odpowiedzialność" (Miłosz, Venclova, 1979, s. 6, 16, 31).
} 
obchody rocznic historyczno-narodowych itd. Kroniki te dawały poczucie wspólnoty losów. Czytelnicy szczególnie cenili obszerne omówienia „Kronik Kościoła Katolickiego na Litwie" (por. Hofman, 2003, s. 224-227). Na innym poziomie przyjmowano eseje Miłosza ukazujące kraj lat dziecinnych poprzez obrazy literackie i pamiętnikarskie (por. Miłosz, 1989, 1991a, 1991b). W miesięczniku opublikowano również prace krytyczno-literackie z zakresu litewskiej literatury emigracyjnej (por. Taylor-Terlecka, 1986; Nyka-Niliunas, 1955).

Najmniej artykułów, gdy mówimy o koncepcji ULB, zarówno politycznych, jak i o tematyce kulturowej, dotyczy Białorusi. Zauważyli to nawet autorzy związani z „Kulturą”. Przykładowo E. Żagiell w jednej z kronik napisał wprost o deficycie treści, wynikającym prawdopodobnie z trudności opisu wspólnej historii Polski, Litwy i Białorusi ${ }^{10}$. Prowadząc rubryką kronikarską, E. Żagiell dokładał starań, aby zachować strukturę wielowątkowej narracji opartej na zróżnicowanych źródłach, co odpowiadało przyjętym w „Kulturze” standardom jakościowego dziennikarstwa. Analizując zawartość kronik białoruskich, można stwierdzić przewagę kilku tematów: walka o odrodzenie świadomości narodowej, stosunki narodowościowe i religijne. Na pewno intensywność tych tematów jest wyróżnikiem zapisów; są one oparte na prasie emigracyjnej. Specyfika kronik wynika z diagnozy Okulicza: unifikacja Białorusi z Rosją (zachowuję oryginalną terminologię publicystyki politycznej) wskutek postanowień traktatu ryskiego i II wojny światowej w zasadzie wykluczyła Białoruś jako podmiot refleksji politologicznej i społecznej (por. Okulicz, 1963, s. 122). W kronikach i nielicznych innych formach wypowiedzi Białoruś występowała w ujęciu stereotypowym - w odniesieniu do uroków przyrody, ludowości, reliktów wielokulturowości. Dopiero w latach 80 . XX wieku dynamika przemian polityczno-społecznych w Europie Wschodniej znalazła odzwierciedlenie w zapisach kronikarskich - w miejscu informacji o codziennym życiu w republice białoruskiej, prześladowaniach religijnych i narodowych pojawiły się przedruki manifestów, apeli dotyczących praw Białorusinów do samostanowienia (por. Hofman, 2003, s. 247-255).

Podobną rolę odgrywały kroniki niemieckie, będące dopełnieniem programu zachodniego i europejskiego. Omawiając projekt niemieckojęzycznego numeru „Kultury”, Mieroszewki w 1952 roku napisał: „Mówiąc słowo Niemcy, każdemu Europejczykowi kłębi się dziś pod czaszką olbrzymi znak zapytania, którego nie można zbyć niemiecką muzyką, kroniką wydarzeń kulturalnych ani

10 „Mało poświęcamy uwagi naszemu wschodniemu sąsiadowi - Sowieckiej Republice Białoruskiej. A z terenu tego wywodzą się przecież: Kościuszko, Mickiewicz, Moniuszko, Syrokomla, Tragutt, Orzeszkowa, Rodziewiczówna, Prez. Raczkiewicz” (Żagiell, 1972, s. 49). 
rozprawą o obecnym stanie literatury niemieckiej" (Giedroyc, Mieroszewski, 1999, s. 121). Punkt widzenia Mieroszewskiego jest zrozumiały o tyle, że był on autorem artykułów programowych, pisanych na zamówienie przez Giedroycia. Artykuły te w dużej mierze były odbiciem rozważań Redaktora o polskiej racji stanu. Kroniki jednak, przynajmniej w pierwszych latach po II wojnie, służyły „oswojeniu” Niemiec jako problemu dyskursu politycznego i medialnego. „Korespondencja z Niemiec” ukazała się w numerze 9/35 w 1950 roku, podpisali ją Eduardo Roditi i Fritz Baumgart; do 1952 roku ukazywała się „Kronika emigracyjna: Niemcy"; w latach 1954, 1955, 1959 i 1960 ukazywał się „Przegląd niemiecki”, opracowywany przez Osadczuka i Kozłowskiego; „Kronikę niemiecką” w latach 1975-1989 rozwinął Chilecki, a następnie w latach 1992-2000 - Andrzej Stach. Inni autorzy związani z tą rubryką to Prądzyński (lata 50. XX wieku) i Grzegorz Ziętkiewicz (epizodycznie w 1989 i 1990 roku). Zdaniem Giedroycia obowiązkiem „Kultury” było informowanie o codziennym życiu Niemców, warunkach socjalnych uchodźców, atmosferze politycznej, wydarzeniach naukowych i kulturowych. Przekonanie to podzielał Mieroszewski, pisząc przykładowo w 1954 roku: „Gdybyśmy dawali stale przegląd spraw niemieckich i poważnych pism - bylibyśmy bardzo uważani przez prasę niemiecką i polityków niemieckich, bo w pewnym sensie mieli-

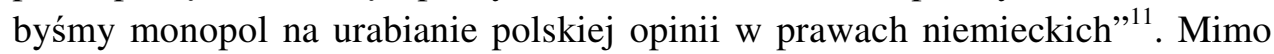
oczywistego politycznego akcentu, kroniki zawierały całościowe omówienia, zgodne z intencją Redaktora. Monopol „Kultury” wynikał raczej z wiarygodności publicystyki politycznej. Kroniki były odczytywane, zgodnie z konwencją i praktyką gatunkową, jako subiektywny przegląd wydarzeń i komentarzy.

Dlaczego Giedroyciowi tak bardzo zależało na możliwie szerokiej prezentacji tematu niemieckiego? Bliski i zaufany współpracownik „Kultury”, Stempowski, już w 1946 roku został wysłany w objazd terenów niemieckojęzycznych; obserwacje i przemyślenia zawarł we wspomnianej już książce Dziennik podróży do Austrii i Niemiec. Na łamach „Kultury” zaś pisał:

Niemcy nie są zjawiskiem prostym. W ciągu krótkiego czasu uległy zmianom większym niż jakikolwiek kraj. Każdy sąd o nich można w tej chwili uważać za przestarzały. Nawet osobom znającym Niemcy powojenne każda nowa podróż dostarcza niespodzianek. Znajomość Niemiec współczesnych w świecie zewnętrznym jest dziś niedostateczna, nieodpowiadająca wcale ani ich roli w obecnej Europie, ani wadze zagadnień z nimi związanych. Dla większości Polaków Niemcy Zachodnie są obecnie zamknięte. Dla emigrantów dokładne poznanie nowych Niemiec, znalezienie w nich

\footnotetext{
${ }^{11}$ List w zbiorach Archiwum Intytutu Literackiego w Maisons-Laffitte.
} 
przyszłych przyjaciół i rozpoznanie zjawisk zwróconych ku przyszłości, wydaje mi się ważnym i dostępnym zadaniem (Hostowiec [ps. Stempowskiego], 1951, s. 12).

Z tych właśnie powodów Giedroyc przywiązywał wagę do publikacji recenzji książek, reportaży, wspomnień, omówień prasy niemieckiej (również z podziałem na strefy wpływów), zapowiedzi stypendiów i możliwości studiowania germanistyki. W latach 1962-1969 ukazało się ponad dwadzieścia tekstów informujących o tej tematyce, w tym: pióra Jeleńskiego, Tadeusza Nowakowskiego, Olgi Scherer, J. Mackiewicza, Kawałkowskiego. W kolejnych latach liczba publikacji utrzymywała się na tym poziomie, ale częściej zamieszczano sprawozdania z konferencji na temat pojednania polsko-niemieckiego. Szaruga wprowadził szerzej literaturę niemiecką jako „pejzaże utracone”, co wyraziście uświadamiało emigrantom i przesiedleńcom wspólnotę losu. Kroniki i publicystyka kulturalna o tematyce niemieckiej wpłynęły na stopniowe porzucanie klisz wytworzonych na podłożu historii i ugruntowanych podczas okupacji hitlerowskiej w Polsce (Hofman, 2009b, s. 88-102, 133-134, 170-172, 220-222, 255-262, 294-310). Niemcom, których los rzucił na obczyznę lub którzy podejmowali próby zmiany nastawienia europejskiej opinii publicznej, strategie Giedroycia przywracały godność i dawały nadzieję na symboliczne odkupienie win. Warto dodać, że w „Kulturze” publikował Władysław Bartoszewski, gorący orędownik pojednania polsko-niemieckiego ${ }^{12}$.

Literatura i kultura polska w programie krajowym „Kultury” to inny poziom realizacji myśli politycznej Giedroycia. Stworzył on kanon literatury emigracyjnej równoległy do ruchu wydawniczego w Polsce, umożliwiając wielu wybitnym twórcom powrót do pisania i wprowadzając w międzynarodowy obieg czytelniczy. Gombrowicz, Miłosz, Bobkowski, Marek Hłasko są powszechnie znanymi przykładami polityki wydawniczej Redaktora. W „Kulturze” znaleźli swoje miejsce pisarze skazani przez cenzurę krajową na zamilczenie, m.in. T. Nowakowski, Stefan Kisielewski, Włodzimierz Odojewski. W kręgu „Kultury” powstała szkoła polskiego eseju, a proza diariuszowa (dzienniki) zyskała mistrzowskie wydania Stempowskiego, Gombrowicza, Herlinga-Grudzińskiego, Tomasza Jastruna. Przeglądając choćby portal „Kultury”, można wymienić następujące nazwiska pisarzy drukowanych przez Instytut: Kazimierz Wierzyński, Józef Wittlin, Czesław Straszewicz, Zygmunt Haupt, Teodor Parnicki, Leopold Tyrmand, Sławomir Mrożek, Marek Nowakowski,

\footnotetext{
${ }^{12}$ W. Bartoszewski był współautorem tekstów Polskiego Porozumienia Niepodległościowego, organizacji założonej w 1976 roku przez Zdzisława Najdera (por. Bartoszewski, 1978, s. 123-129; 1980, s. 75-81; 1986, s. 95-105).
} 
Zbigniew Herbert, Kazimierz Brandys, Bobkowski, Wacław Iwaniuk, Stanisław Vincenz, Kazimierz Orłoś, Bohdan Madej, Wiktor Woroszylski, Jacek Bierezin, Stanisław Barańczak, Ryszard Krynicki, Adam Zagajewski, Andrzej Chciuk. Nie jest to lista kompletna, ale pokazuje zakres i wpływy Instytutu Literackiego. Publikacje na łamach „Kultury” lub w formie książek zawsze poprzedzała obszerna korespondencja, z której wynika, jak troskliwy i dbały o autorów był Giedroyc ${ }^{13}$. Udzielał im stałej pomocy materialnej, gdy była taka potrzeba - gościny w domu w Maisons-Laffitte (choćby wspomnieć dramatyczne okoliczności pobytu Miłosza po jego ucieczce z Polski w 1951 roku), poszukiwał dla nich stałych zajęć zarobkowych, zabiegał o tłumaczy i recenzentów, dzieląc $\mathrm{z}$ autorami radości $\mathrm{z}$ wydania książek, konspirował (wobec autorów wracających do Polski), sprawdzał terminowość korekt i druku, dystrybuował książki i promował autorów w prasie europejskiej. Redaktor osiągnął niebywałą skuteczność w organizacji pomocy dla pisarzy i skłonienia ich do podjęcia ryzyka powojennego debiutu, adresowanego właściwie do czytelników-emigrantów. Należy podkreślić, że rozumiejąc doskwierające poczucie obcości, Giedroyc zajął w 1956 roku inne stanowisko wobec powrotu pisarzy do Polski niż Związek Pisarzy Polskich na Obczyźnie. Uważał, że książki pisarzy na emigracji mogą być drukowane za żelazną kurtyną, a jeśli warunki egzystencjalne autorów są złe, usprawiedliwiał powroty.

Tematyka kulturowa i kulturalna były stale obecne na łamach „Kultury” przez cały okres wydawania miesięcznika jako ważny element programów politycznych skoncentrowanych na projektowaniu miejsca i roli Polski niepodległej w jednoczącej się Europie, w dobrosąsiedzkich relacjach z Ukrainą, Litwą, Białorusią, Niemcami. Giedroyc był prekursorem strategii oddziaływania na opinię publiczną przez łączenie tematyki politycznej i kulturalnej. Uważał, że przekaz o kulturze ułatwi porozumienie w zasadniczych kwestiach politycznych, gdyż umożliwi poznanie wspólnej historii i aspiracji narodowych oraz przyczyni się do odrzucenia klisz myślowych, utrwalonych wskutek dramatycznych wydarzeń w XX wieku. Redaktor traktował tematykę kulturalną i literaturę pragmatycznie. W świetle korespondencji można powiedzieć, że skupiał się na scenariuszach i analizach polityki, cedując niejako sprawy literatury na swoich współpracowników, przede wszystkim HerlingaGrudzińskiego, a później Szarugę.

\footnotetext{
${ }^{13}$ W serii wydawniczej Archiwum „Kultury”, prowadzonej przez wydawnictwo „Czytelnik”, a obecnie „Więź”, ukazała się korespondencja do 25 autorów, w tym monumentalne opracowanie listów do Miłosza i Mieroszewskiego; poza serią ukazały się zbiory listów do Herlinga-Grudzińskiego, Nowaka-Jeziorańskiego, Ungera. Omówienia tych korespondencji znajdują się m.in. w: Kowalczyk, 2006; zob. też Hofman, 2015, s. 559-574.
} 
Dzieje miesięcznika dowiodły, że nawet w warunkach emigracyjnych i przy dominancie myśli niepodległościowej funkcja kulturotwórcza stanowi istotną miarę recepcji mediów. Giedroyc mógł z satysfakcją obserwować zmiany w postawach Polaków (również krajowców) wobec sąsiadów, a nawet szerzej - wobec Innego, racjonalizację stosunku do dziedzictwa historycznego i kulturowego, gotowość do współpracy w ramach wspólnoty narodów Europy Wschodniej. „Kultura” zyskała szacunek jako czasopismo i ośrodek myśli politycznej wysoko pozycjonujący literaturę, przez nią bowiem następowało zbliżenie między Polakami, Ukraińcami, Litwinami, Białorusinami i Niemcami. Adresaci czasopisma dobrze odczytywali intencje Giedroycia, aby rzetelnie informując, gromadzić kapitał zaufania procentujący w akceptacji założeń programowych. Specjalnym polem weryfikacji wiarygodności „Kultury” była sfera literacka i kroniki, najbardziej jasny przekaz zrozumienia i pojednania między narodami.

\section{BIBLIOGRAFIA}

Bartoszewski W. (1978), Niemcy a Polska, Kultura, nr 7/270-8/371, s. 123-129.

Bartoszewski W. (1980), O stosunkach z Niemcami, Kultura, nr 5/392, s. 75-81.

Bartoszewski W. (1986), Przemówienie Wtadysława Bartoszewskiego we Frankfurcie, Kultura, nr 11/470, s. 95-105.

Chruślińska I. (2003), Była raz „Kultura”. Rozmowy z Zofia Hertz, Lublin: Wydawnictwo UMCS.

Droga na Wschód. Z Jerzym Giedroyciem rozmawia Marek Zieliński (1989), Więź, nr 10, s. 42-50.

Friszke A. (2007), Przystosowanie i opór. Studia dziejów PRL, Warszawa: Wydawnictwo Więź.

Friszke A., Habielski R., Machcewicz P. (1999), Życie polityczne, społeczne i kulturalne emigracji, Wrocław: Wydawnictwo Więź.

Giedroyc J. (1994), Autobiografia na cztery ręce, oprac. i posłowie K. Pomian, Warszawa: „Czytelnik".

Giedroyc J., Mieroszewski J. (1999), Listy. 1949-1956, wybór i wstęp K. Pomian, Warszawa: Czytelnik.

Habielski R. (1991), Niezłomni, nieprzejednani. Wiadomości i ich krag 1940-1981, Warszawa: PIW.

Habielski R. (1997), Realizm, wizje i sny romantyków. O pisarstwie Juliusza Mieroszewskiego, [w:] J. Mieroszewski, Finat klasycznej Europy, Lublin: Wydawnictwo UMCS, s. 23-34.

Habielski R. (2000), Polski Londyn, Wrocław: Wydawnictwo Dolnośląskie.

Hofman I. (2002), Kroniki emigracyjne Kultury. Rekonesans badawczy, Annales Universitatis Mariae Curie Skłodowska, Sectio K. Politologia, vol. 9, s. 87-99.

Hofman I. (2003), Ukraina, Litwa, Białoruś w publicystyce paryskiej Kultury, Poznań: Forum Naukowe.

Hofman I. (2007), Jerzego Giedroycia i Jana Nowaka Jeziorańskiego myślenie o nowej Polsce, Studia o Polityce, nr 20, s. 181-203. 
Hofman I. (2009a), Juliusz Mieroszewski: między paryska Kultura o RP RWE, [w:] M. Kosman (red.), Na obrzeżach polityki, Poznań: Wydawnictwo Naukowe WNPiD UAM, cz. 7, s. 207-224.

Hofman I. (2009b), Polska, Niemcy, Europa. Program zachodni paryskiej Kultury, Lublin: Wydawnictwo UMCS.

Hofman I. (red.) (2011), Wokót idei Jerzego Giedroycia, Lublin: Wydawnictwo UMCS.

Hofman I. (2015), Listy jako forma komunikacji politycznej, [w:] E. Maj (red.), Myśl polityczna $w$ dobie społeczeństwa informacyjnego, Lublin: Wydawnictwo UMCS, s. 559-574.

Hofman I. (2018), Listy Jerzego Giedroycia i Leopolda Ungera, [w:] K. Leszczyńska (red.), W kręgu historii, politologii i emigracji, Toruń: Wydawnictwo A. Marszałek, s. 253-266.

Hofman I. (2019), Redaktor. 20 lat bez Kultury, Lublin: Wydawnictwo UMCS.

Hofman I., Unger L. (2010), (red.), Teczki Giedroycia, Lublin: Wydawnictwo UMCS, Paryż: Instytut Literacki.

Hostowiec P. (1951), List w sprawach niemieckich, Kultura, nr 2/240-3/241, s. 10-13

Kerski B., Kowalczyk A.S. (2001), Wiek ukraińsko-polski. Wiek ukraińsko-polski. Rozmowy z Bohdanem Osadczukiem, Lublin: Wydawnictwo UMCS.

Kopczyński K. (1990), Przed przystankiem Niepodległość. Paryska Kultura i Kraj w latach 19801989, Warszawa: Wydawnictwo Więź.

Korek J. (2000), Paradoksy paryskiej Kultury, Lublin: Wydawnictwo UMCS.

Kowalczyk A.S. (1999), Giedroyc i Kultura, Wrocław: Wydawnictwo Dolnośląskie.

Kowalczyk A.S. (2006), Od Bukaresztu do Laffitów. Jerzego Giedroycia rzeczpospolita epistolarna, Sejny: Wydawnictwo Pogranicze.

Kudelski Z. (red.), (1995), Spotkanie z paryska Kultura, Warszawa: Wydawnictwo Więź.

Ławrynenko J. (1959), Literatura sytuacji pogranicznych, Kultura, nr 3/137, s. 5-17.

Łobodowski J. (1951), Ukraińska literatura emigracyjna, Kultura, nr 4/54, s. 46-60.

Łobodowski J. (1952), Przeciw upiorom przeszłości, Kultura, nr 2/52-3/52, s. 14-66.

Łobodowski J. (1954), Scylle i Charybdy ukraińskiej poezji, Kultura, nr 5/79, s. 35-50; nr 6/80, s. 24-49.

Łobodowski J. (1955), Poezja Jewhena Małaniuka, Kultura, nr 10/96, s. 32-38.

Łobodowski J. (1959), Młody las na obczyźnie, Kultura, nr 10/156, s. 49-58.

Łobodowski J. (1966a), Sąd nad umartym, Kultura, nr 6/224, s. 3-8.

Łobodowski J. (1966b), O Maksymie Rylskim, Kultura, nr 7/225-8/226, s. 30-37.

Majewski J. (1952), List, Kultura, nr 11/61, s. 157-158.

Mieroszewski J. (1956), Materiaty do refleksji, Kultura, nr 3/101, s. 75-83; 4/102, s. 73-78.

Mieroszewski J. (1957), Analiza widma, Kultura, nr 3/113, s. 53-59.

Mieroszewski J. (1962), Zaduma noworoczna, Kultura, nr 1/171-2/172, s. 151-161.

Mieroszewski J. (1964), Geoideologia, Kultura, nr 12/206, s. 3-12.

Mieroszewski J. (1966), ABC polityki Kultury, Kultura, nr 4/222, s. 40-52.

Mieroszewski J. (1967a), Pewne rzeczy nazwane po imieniu, Kultura, nr 4/234, s. 72-81.

Mieroszewski J. (1967b), Tytut zostaje ten sam, Kultura, nr 12/242, s. 33-42.

Mieroszewski J. (1967c), Ani z Rosja, ani z Niemcami, Kultura, nr 9/239, s. 34-44.

Mieroszewski J. (1970), Może zdarzyć się i tak, Kultura, nr 4/271, s. 47-53. 
Mieroszewski J. (1972), O banałach i cudach w polityce, Kultura, nr 4/295, s. 79-90.

Mieroszewski J. (1973a), Polska Ostpolitik, Kultura, nr 6/309, s. 68-79.

Mieroszewski J., (1973b), Polska Westpolitik, Kultura, nr 9/312, s. 45-56.

Mieroszewski J. (1974), Rosyjski kompleks Polski i obszar ULB, Kultura, nr 9/324, s. 3-15.

Mieroszewski J. (1997), Finat klasycznej Europy, Lublin: Wydawnictwo UMCS.

Miłosz Cz. (1989), Koniec Wielkiego Xięstwa (O Józefie Mackiewiczu), Kultura, nr 5/500, s. 102-120.

Miłosz Cz. (1991a), Nad Niewiaża, wiek dziewiętnasty, Kultura, nr 5/524, s. 24-46.

Miłosz Cz. (1991b), Rodziewiczówna, Kultura, nr 3/522, s. 9-30.

Miłosz Cz., Venclova T. (1979), Dialog o Wilnie, Kultura, nr 1/376-2/377, s. 3-35.

Nota Redakcji. Nieporozumienie czy tani patriotyzm, (1953), Kultura, nr 1/63, s. 82-83.

Nowinowski S.M. (2019), Jerzy Giedroyć w 1946 roku, Gdańsk: Wydawnictwo słowo/obraz terytoria.

Nyka-Niliunas A. (1955), Najnowsza poezja litewska, Kultura, nr 10/96, s. 57-62.

Okulicz K. (1963), Białoruś sowiecka, Kultura, nr 5/187, s. 121-126.

Pomian G. (1995), Emigracja i emigranci, [w:] „Kultura” i jej krag 1946-1986. Katalog wystawy czterdziestolecia Instytutu Literackiego, Lublin: Wydawnictwo UMCS, s. 143-150.

Pomian K. (1999), Aktualność Mieroszewskiego, [w:] J. Giedroyc, J. Mieroszewski, Listy 1949-1956, wybór i wstęp K. Pomian, Warszawa: Wydawnictwo „Czytelnik”, s. 5-33.

Pomian K. (2000), W kręgu Giedroycia, Warszawa: Wydawnictwo „Czytelnik”.

Rodak P. (2011), Między zapisem a literaturą. Dzienniki polskiego pisarza w XX wieku, Warszawa: Wydawnictwo UW.

Szaruga L. (2001), Kultura i przyszłe stosunki polsko-niemieckie, [w:] K. Pomian (red.), Jerzy Giedroyc. Redaktor, Polityk, Człowiek, Lublin: Wydawnictwo UMCS, s. 235-250.

Taylor-Terlecka N. (1986), Dziedzictwo W.X. Litewskiego w literaturze emigracyjnej, Kultura, nr 10/469, s. 124-136.

Venclova T. (1989), List otwarty do Litwinów i Polaków, Kultura, nr 3/498, s. 111-114.

Żagiell E. (1972), Białorusini, Kultura, nr 6/297, s. 49-55.

\section{KULTURA W PROGRAMACH JERZEGO GIEDROYCIA}

\section{Streszczenie}

Celem artykułu jest przedstawienie tematyki kulturalnej z łamów „Kultury” paryskiej w kontekście kulturotwórczej funkcji mediów oraz medialnych strategii dyplomacji kulturalnej. „Kultura” paryska ukazywała się w latach 1946-2000 jako periodyk Instytutu Literackiego w Paryżu, jej twórcą i redaktorem był Jerzy Giedroyc. Ze względu na odrębność programową (postawienie na kontakty z Krajem) i wysokiej próby publicystykę, była postrzegana jako ośrodek myśli politycznej realizujący niepodległościowe założenia ideowe poprzez koncepcje dobrosąsiedzkich stosunków Polski z Ukrainą, Litwą, Białorusią i Niemcami w warunkach geopolitycznych zmian w Europie po upadku ZSRR i zjednoczeniu Niemiec. Artykuły programowe pisali m.in. Juliusz Mieroszewski, Jerzy Stempowski, Bohdan Osadczuk, Leopold Unger. Giedroyc dbał o proporcje materiałów politycznych i kulturalnych w numerach czasopisma, a co ważniejsze - udostępniał łamy twórcom 
z obszaru ULB. Był pomysłodawcą cyklu kronik, m.in. ukraińskiej, litewskiej, białoruskiej, niemieckiej, oraz przeglądów prasy, które stanowiły podstawowe źródło informacji o życiu emigrantów i o życiu w ich opuszczonych ojczyznach. Giedroyc, za pomocą „Kultury”, realizował strategię oddziaływania na opinię publiczną przez łączenie tematyki politycznej i kulturalnej, gdyż był przekonany, że w ten sposób przyczyni się do odrzucenia stereotypów i umożliwi poznanie wspólnej historii i kultury.

Słowa kluczowe: emigracja; dyplomacja kulturowa; Giedroyc; kroniki; funkcje mediów.

\section{CULTURE IN JERZY GIEDROYC'S PROGRAMMES}

Summary

The article aims to present the cultural matters from "Kultura" (Paris-based "Culture") in the context of the cultural-creative function of the media and media strategies of cultural diplomacy. "Kultura" was published in 1946-2000 as a periodical of the Institute of Literature in Paris, its creator and editor was Jerzy Giedroyc. Due to its program distinctiveness (the stake in contacts with the country) and high publicity effort, it was perceived as a centre of political thought pursuing the independence ideals through the concepts of good neighbourly relations between Poland and Ukraine, Lithuania, Belarus and Germany in the conditions of geopolitical changes in Europe after the dissolution of the USSR and German reunification. The programme articles were written by Juliusz Mieroszewski, Jerzy Stempowski, Bohdan Osadczuk, Leopold Unger, among others. Giedroyc paid attention to the balance of political and cultural content in the issues of the magazine, and what is more important, he let authors from Ukraine, Lithuania and Belarus to publish in the magazine. $\mathrm{He}$ was the originator of a series of chronicles, including ones concerning Ukraine, Lithuania, Belarus, Germany, and press reviews, which were the basic source of information about the lives of emigrants and life in their abandoned homelands. Giedroyc, through "Kultura," pursued a strategy of influencing public opinion by combining political and cultural matters because he was convinced that in this way he would contribute to the rejection of stereotypes and make it possible to learn about common history and culture.

Keywords: emigration; cultural diplomacy; Giedroyc; chronicles; media functions. 